\title{
A transformação da natureza e as potencialidades do monitoramento ambiental na Lagoa Urbana Olho d'Água - PE: os desafios da complexa relação entre desenvolvimento urbano e a conservação de ambientes naturais
}

\author{
The transformation of nature and the potentialities of environmental monitoring in the \\ urban Lake Olho D'Água-PE: the challenges of the relationship between urban development \\ and the conservation of natural environments
}

\author{
Elisabeth Regina Alves Cavalcanti Silva ${ }^{1}$ \\ Sidney Henrique Campelo de Santana ${ }^{2}$ \\ José Gustavo da Silva Melo ${ }^{3}$ \\ Sandra Maria Mendes ${ }^{4}$ \\ Josiclêda Domiciano Galvíncio ${ }^{5}$
}

\begin{abstract}
Resumo
O intenso crescimento urbano das cidades acarreta o surgimento de uma série de problemáticas em relação à conservação dos ambientes naturais. Por essa razão, o estudo de caso de que trata este trabalho corresponde à área da Lagoa Olho d'Água, que é a principal lagoa natural costeira do estado de Pernambuco e a maior lagoa urbana do Brasil. Nas últimas décadas, o perímetro urbano tem se adensado na área devido à beleza cênica, o que, consequentemente, acarreta uma especulação imobiliária no entorno da lagoa. Dessa forma, o objetivo deste trabalho é analisara transformação da natureza e as potencialidades do monitoramento ambiental na Lagoa Urbana Olho d'Água - PE, considerando os desafios existentes na relação, muitas vezes antagônicas, entre desenvolvimento urbano e a conservação de ambientes naturais a partir da avaliação espaçotemporal da área através de sensoriamento remoto e processamento digital de imagens de satélite. Foram utilizadas na avaliação, com base em índices de vegetação,2 variáveis biofísicas: o índice de vegetação por diferença normalizada (NDVI) para avaliação do conteúdo de clorofila na vegetação e o índice de vegetação ajustado ao solo (Savi) para identificação de focos de degradação na área. Foram utilizadas três imagens do satélite Landsat dos anos de 1989, 2000 e 2010. O estudo demonstrou que a vegetação apresentou uma considerável diminuição do ano de 1989 até 2010 devido ao adensamento urbano ocorrido nas últimas décadas. Os resultados demonstrados contribuem para o planejamento da conservação ambiental, para a gestão e o monitoramento ambiental contínuo da Lagoa Olho d'Água.
\end{abstract}

Palavras-chaves: Degradação ambiental. Planejamento. Sensoriamento remoto. Urbanização.

\footnotetext{
Abstract

1 Professora EBTT de Engenharia Ambiental do IFMA. Doutoranda do Programa de Pós-Graduação em Desenvolvimento Ambiental pela Universidade Federal de Pernambuco. E-mail: elisabeth.silva@ifma.edu.br

${ }^{2}$ Doutorando em Geografia (UFPE). E-mail: sidney@ hotmail.com

${ }^{3}$ Mestre em Desenvolvimento Urbano (UFPE).E-mail: sandra_mendes@hotmail.com

${ }^{4}$ Mestre em Desenvolvimento e Meio Ambiente (UFPE). E-mail: josegustavo_melo@ hotmail.com

${ }^{5}$ Coordenadora do Programa de Pós-Graduação em Desenvolvimento e Meio Ambiente (PRODEMA-UFPE). E-mail: josicleda@hotmail.com
} 
The intense urban growth of the cities causes the emergence of a series of problems in relation to the conservation of natural environments. For this reason, the case study of this work corresponds to the area of Lago Olho d'Água, which is the main coastal natural lagoon of the State of Pernambuco and the largest urban lagoon in Brazil. In the last decades the urban perimeter has become denser in the area attracted by the scenic beauty which, consequently, entails a real estate speculation around the Lagoa. Thus, the objective of this work is to analyze the transformation of nature and the potential of environmental monitoring in the Olho d'Água - PE urban lagoon, considering the challenges in the relationship, often antagonistic, between urban development and the conservation of natural environments. from the space-time evaluation of the area through remote sensing and digital processing of satellite images. Based on vegetation indexes, two biophysical variables were used: the vegetation index by normalized difference (NDVI) to evaluate the chlorophyll content in the vegetation and the vegetation index adjusted to the soil (Savi) for the identification of foci degradation in the area. Three images of the Landsat satellite of the years 1989, 2000 and 2010 were used. The study showed that the vegetation showed a considerable decrease from 1989 to 2010 due to the urban densification that occurred in the last decades. The results demonstrated contribute to the planning of environmental conservation and to the management and continuous environmental monitoring of Lago Olho d'Água.

Keywords: Environmental degradation. Planning. Remote sensing. Urbanization.

\section{Introdução}

Na Idade Contemporânea, a influência do Positivismo de Augusto Comte (em sua ênfase pelo conhecimento científico) contribuiu para que houvesse, nos dias de hoje, o surgimento das primeiras preocupações ambientais da relação do homem x natureza, bem como a crítica ao nosso modelo de "desenvolvimento" apoiado no uso massivo dos recursos ambientais, procurando enxergar a natureza não apenas como criação de Deus para servir ao homem, tampouco como um ser que tenha suas próprias vontades, mas em uma visão holística de conjunto em constante interação.

Passmore (1995, p.91) reflete sobre "quais devem ser nossas atitudes frente à natureza", tendo em vista o entendimento delimitado da expressão natureza, que para o autor: "exclui tanto o humano quanto o artificial”. Aprofundando-se na questão em relação à natureza, o autor observa que ela é "passível de modificação pelo poder do homem", ou seja, pode ser destruída pela ação deste. O autor também relata acerca das condições gerais que qualquer filosofia da natureza deva preencher para atender aos temas científicos do movimento ecológico:

1) Que os processos naturais têm seus próprios cursos, de forma indiferente aos interesses humanos [...] 2) Quando os homens atuam sobre a natureza, eles não modificam simplesmente uma qualidade particular de uma substância particular. O que eles fazem, realmente, é interagir com um sistema de interações, colocando em andamento novas interações. É precisamente por essa razão que existe sempre 
o risco de que suas ações tenham consequências por eles não previstas. 3) Em nossa tentativa de entender a natureza, a descoberta de leis gerais, do modelo da física, tem frequentemente uma importância muito limitada. A queixa de que a biologia e a sociologia são inferiores porque elas não têm leis pode ser invertida e utilizada como um argumento contra uma ênfase indevida sobre a análise platônico-cartesiana da "compreensão". Quando se trata de entender as estruturas biológicas ou sociais, podemos dizer que o que importa é a compreensão detalhada de circunstâncias muito específicas, mais do que o conhecimento de relações funcionais de alto nível [...] (PASSMORE, 1995, p. 98).

Entretanto, não é possível realizar uma análise sistêmica do meio, tampouco da relação entre os atores envolvidos nos processos estudados, sem levar em consideração todo um arcabouço teórico-metodológico e os conceitos que atuam como pano de fundo dessa relação. É através desse resgate conceitual sobre os diferentes olhares do homem frente à natureza que se poderá compreender as razões que levaram à atual concepção humana sobre a natureza.

E é a partir desse olhar que podemos entender as formas do ser humano lidar com a natureza e com o meio ambiente, tendo em vista o conceito de meio ambiente definido pelo Art. 3 da Política Nacional de Meio Ambiente (1981) como: “o conjunto de condições, leis, influência e interações de ordem física, química, biológica, social, cultural e urbanística, que permite, abriga e rege a vida em todas as suas formas", ou seja, o conceito adotado na política ambiental brasileira abrange as relações entre a natureza e os seres humanos quando define a vida em todas as suas formas e a relação do homem sobre o espaço no qual ele atua.

Essa relação homem versus ambiente carrega toda uma complexidade inerente ao modo como o homem enxerga o meio ambiente e é a sua visão sobre o mundo que permeia suas decisões como parte da sociedade. A partir do momento que o homem encara a sociedade como um todo e percebe que ela é responsável pela preservação do meio ambiente, então, é preciso agir da melhor maneira possível para não o modificar de forma negativa, pois isso terá consequências para a qualidade de vida da atual e das futuras gerações. Por essa razão, o Art. 225 da Constituição Federal procura estabelecer a ideia de que:

Todos têm direito ao meio ambiente ecologicamente equilibrado, bem de uso comum do povo e essencial à qualidade de vida, impondo-se ao poder público e à coletividade o dever de defendê-lo e preservá-lo para as presentes e futuras gerações.

Desse modo, como sugere Passmore (1995), deve-se salientar a necessidade de construir novas atitudes frente à natureza, tendo em vista a racionalidade ambiental, para que seja possível não só manter, como também expandir a visão sobre o conceito de natureza e sua importância no 
processo de produção do espaço urbano. A relevância desse tema reside, sobretudo, no fato de que urge a implementação de práticas urbanísticas e de políticas públicas, que passem a usar o território no âmbito da valorização e do respeito da sua complexidade e poética, conservando sua beleza (CASTILHO et al., 2016).

Nesse sentido, tem se intensificado nas últimas décadas o processo de urbanização no país, onde a população brasileira deixou de ser predominantemente rural, no período 1960-1970, e passou a ocupar as cidades, intensificando o processo de adensamento urbano. Segundo Mucelin e Bellini (2008), são as constantes criações das cidades e as crescentes ampliações das áreas urbanas, geralmente providas das migrações entre regiões pobres e as grandes metrópoles, que têm contribuído de maneira significante para a intensificação dos impactos ambientais.

Por essa razão, estudos que analisam o crescimento urbano e a dinâmica ambiental de determinados locais podem oferecer alternativas para melhorar o planejamento, gestão e monitoramento da dinâmica dos ambientes naturais frente à modificação nos padrões naturais de lugares de interesse para a conservação ambiental (FEIO; AGUIAR-DIAS, 2017). Como consequência da expansão desordenada das cidades, surgem problemas ambientais nas áreas urbanas ocasionados pela degradação dos recursos naturais (SOARES; LEAL, 2011).

Em razão do adensamento do tecido urbano, muitas vezes a falta de planejamento no crescimento das cidades leva à ocupação de áreas de sensibilidade ambiental. Com isso, surgem problemas que exigem uma atuação em conjunto do planejamento e da gestão urbana. Dessa forma, o planejamento urbano e ambiental é um instrumento importante na conservação e recuperação de áreas ambientais degradadas (ARANA, 2016).

Nesse sentido, foi realizado um estudo de caso na região metropolitana do Recife, mais precisamente no município de Jaboatão dos Guararapes. O local foi escolhido por se tratar de um território marcado por diferentes relações de poder, em que o crescimento econômico das últimas décadas culminou por incentivar a expansão imobiliária e o adensamento urbano sobre áreas naturais, causando degradação ambiental em áreas que anteriormente eram utilizadas pela população para recreação, subsistência e refúgio de várias espécies, como a Lagoa Olho d’Água.

\section{A importância da conservação de lagoas costeiras a partir da sua relevância no território}

As margens de corpos d'água são definidas como Áreas de Preservação Permanente (APP) pelo Código Florestal Brasileiro (Lei Federal no 12.651/2012). Trata-se de um mecanismo legal 
criado para proteção das áreas ambientalmente sensíveis, assim como encostas íngremes, topos de morro, mangues, dunas, margens de rios e lagos. O conceito de APP embute a limitação de diversas formas de uso e ocupação das terras (MELLO, 2009), tais como a limitação de terras para agricultura e pecuária, urbanização etc. Segundo o novo Código Florestal - Lei no 12.651/2012, que dispõe sobre a proteção da vegetação nativa, no Art. $3^{\circ}$ fica definido:

II - Área de Preservação Permanente - APP: área protegida, coberta ou não por vegetação nativa, com a função ambiental de preservar os recursos hídricos, a paisagem, a estabilidade geológica e a biodiversidade, facilitar o fluxo gênico de fauna e flora, proteger o solo e assegurar o bem-estar das populações humanas.

Os limites das APP para o entorno de lagoas e lagos naturais já estavam contemplados, segundo a Resolução CONAMA (303/2002), na Lei n n $^{\circ} .771 / 1965$ e suas modificações (revogada em maio de 2012 pela instituição do novo Código Florestal), que apresentava a seguinte redação sobre a área de preservação permanente na área de influência de lagos e lagoas naturais:

I - ao redor de lagos e lagoas naturais, em faixa com metragem mínima de: a) trinta metros, para os que estejam situados em áreas urbanas consolidadas; b) cem metros, para as que estejam em áreas rurais, exceto os corpos d água com até vinte hectares de superfície, cuja faixa marginal será de cinquenta metros.

Houve pouca modificação da redação a partir do novo Código Florestal. Segundo a Lei Federal n $n^{\circ}$ 12.651/2012, com as modificações pela Lei n n $^{\circ}$ 2.727/2012, Seção I - Da delimitação das áreas de Preservação Permanente:

as áreas no entorno dos lagos e lagoas naturais, em faixa com largura mínima de: a) 100 (cem) metros, em zonas rurais, exceto para o corpo d'água com até 20 (vinte) hectares de superfície, cuja faixa marginal será de 50 (cinquenta) metros; b) 30 (trinta) metros, em zonas urbanas.

As lagoas são definidas como corpos rasos de água salgada, doce ou salobra, onde a radiação solar pode alcançar o sedimento, possibilitando o crescimento de macrófitas aquáticas em toda sua extensão (ESTEVES, 1998), classificando os compartimentos desse ecossistema lacustre como uma região de interface água-ar. Esse é um conceito similar ao apresentado por Guerra; Guerra (2011), os quais afirmam que as lagoas são depressões de pequenas profundidades, com variadas formas, especialmente circulares.

Para Loureiro et al. (2006), as lagoas costeiras são corpos d'água conectados ao oceano e formados como resultado da elevação do nível do mar durante o Holoceno/Pleistoceno e da 
construção das restingas arenosas através dos processos marinhos, isolando parcialmente ou totalmente os corpos lagunares do oceano. Segundo Tundisi e Matsumura-Tundisi (2008), define-se lagoa costeira como um lago raso ou como corpos de água conectados a um rio ou ao mar. Já para Kjerfve (1984), a definição para lagoa costeira é a de um conjunto de água rasa, costeiro, separado do oceano por uma barreira, conectado pelo menos intermitentemente com o oceano, por uma ou mais conexões restritas e normalmente com orientação paralela à costa.

As lagoas representam $15 \%$ da zona costeira de todo o mundo e estão entre os ecossistemas mais produtivos da biosfera (NASCIMENTO, 2010). Segundo Barroso et al. (2000):

estes corpos d'água servem a diversas atividades antrópicas relacionadas com a alimentação, energia, transporte, recreação e urbanismo e o seu balanço natural pode ser facilmente perturbado, muitas vezes de forma irreversível e sempre acompanhado de problemas socioeconômicos.

Para Nascimento (2010), os ecossistemas lacustres (lagos, lagoas e lagunas), principalmente as lagoas costeiras como a Olho d'Água, têm grande importância, tanto para as diversas atividades que elas oferecem para os seres humanos como também para o equilíbrio do ecossistema presente. Segundo Esteves (1998), as lagoas costeiras contribuem para:

(I) a manutenção do lençol freático;

(II) a estabilidade climática local.

Segundo o Decreto $n^{\circ}$ 6.678, de 8 de dezembro de 2008 (BRASIL, 2008) a Zona Costeira é responsável por muitas "funções ecológicas”, tais como: “a preservação de inundações, a intrusão salina e a erosão costeira; a proteção contra tempestades; a reciclagem de nutrientes e de substâncias poluidoras; a provisão de habitats e recursos para uma variedade de espécies exploradas direta e indiretamente". Os ecossistemas dessa zona de maior relevância são os estuários, os manguezais e as lagoas costeiras, bem como os banhados e as áreas úmidas costeiras.

Dessa forma, o planejamento dos espaços nas margens de corpos d'água apresenta-se como um dos grandes desafios da pauta de gestão ambiental urbana contemporânea. Para autores como Lima (1996), a abordagem do tema implica o enfrentamento das relações dicotômicas envolvidas. Por um lado, a proximidade da água orienta a estruturação da cidade ao longo da história e os espaços em margens de corpos d'água sempre desempenharam importantes funções urbanas. Por outro, as zonas ripárias - que constituem os ecossistemas próprios das áreas às margens de corpos d'água - são as áreas mais dinâmicas da bacia hidrográfica, em termos hidrológicos, geológicos, geomorfológicos e ecológicos, desempenhando funções ambientais essenciais como a produção de 
matéria e energia (fotossíntese), a reciclagem de matéria (ciclos biogeoquímicos) e a manutenção do equilíbrio de gases na atmosfera.

Segundo Assis (2013), a Lagoa Olho d'Água é um ecossistema comumente utilizado pela população a fim de obter alimentos para sua sobrevivência ou para a de seus dependentes. Contudo, esses usos e ocupações possuem seus limites, notadamente em função da vulnerabilidade do referido ecossistema à ação antrópica, seja pelo intenso processo de urbanização das últimas décadas, seja pelos esgotos lançados ou pela extração de areia.

Segundo Gomes et al. (2003), além da expansão urbana intensa na área da lagoa, ainda existe o problema da extração de areia, que é feita no leito dos rios, na Lagoa Olho d'Água e nos terraços fluviais e marinhos realizada por empresas de médio a grande porte, geralmente com autorização legal para exercer a atividade. Os impactos ambientais causados por essas minerações são bem maiores do que os causados pelas atividades informais, acarretando no assoreamento dos rios, lagoas e canais fluviais, na contaminação do lençol freático e das águas superficiais e o desaparecimento de espécies nativas (flora e fauna) quando há a remoção da vegetação.

\section{Caracterização territorial da Lagoa Olho d'Água e sua importância ambiental}

O município de Jaboatão dos Guararapes, importante território da Região Metropolitana do Recife, é cortado pelo Rio Jaboatão, que percorrendo a cidade, a cada curva e a cada aglomeração que se estabelece em suas águas, vai sendo poluído e contaminado. Também conhecido pelo seu litoral e sistema estuarino, Jaboatão dos Guararapes enfrenta muitos conflitos com suas águas urbanas. As águas urbanas estão atreladas a problemas na conservação da paisagem na Região Metropolitana do Recife. Problemas de drenagem e saneamento são desafios à constituição de uma paisagem de águas que permaneça no imaginário das pessoas relacionada ao bem-estar e ao aprazível na Grande Recife (TENÓRIO, 2013).

Segundo Assis et al. (1997), a partir da década de 1940 o município de Jaboatão dos Guararapes apresenta um processo acelerado de adensamento demográfico, principalmente no período de 1980 a 1990 em que a população do município dobrou. O município apresenta, assim, uma taxa de $478 \%$ de crescimento em 30 anos, concentrando-se predominantemente na orla marítima. $\mathrm{O}$ acentuado aumento de edificações que atendiam inicialmente uma população de médio a alto poder aquisitivo na orla marítima atraiu mão de obra para construção civil, a qual acabou 
alojando-se nas áreas adjacentes, precisamente nos arredores da Lagoa Olho d'Água, somando-se à população já existente nessa localidade (EMDEJA, 2003).

A Lagoa Olho d'Água, também conhecida como Lagoa do Náutico, está localizada no município de Jaboatão dos Guararapes - PE, na Região Metropolitana do Recife. A área de estudo é a principal lagoa natural na costa de Pernambuco, sendo uma das maiores dentro de zona urbana no Nordeste e no país, além de ser a maior lagoa de formação de restinga em área urbana do Brasil (PAIVA; SALGUEIRO, 2002). Seu espelho d'água tem uma área de $3,75 \mathrm{~km}^{2}$, possuindo aproximadamente 3,5 km de comprimento por 1,9 km de largura, sendo maior que a Lagoa Rodrigo de Freitas no Rio de Janeiro, onde o espelho d'água possui cerca de 2,5km² (ANDREATA et al., 1997; BRASIL, 1997; BAPTISTA NETO et al., 2011).

Segundo propõe o Plano Diretor do município de Jaboatão dos Guararapes sobre a ZCA Zona de Conservação dos Corpos d'Água, no qual o entorno da Lagoa do Náutico (ZCA 2) está contido, o perímetro da lagoa inicia-se no ponto de partida e fechamento de coordenadas $\mathrm{E}=286504.075$ e N=9094860.239. A lagoa em si também é singular por ser um meio de ligação hídrica entre dois estuários da Região Metropolitana do Recife. Através do Canal Olho d'Água ligase ao estuário formado pela foz dos rios Jaboatão e Pirapama, em Barra de Jangada, e através do Canal Setúbal ao estuário do Rio Pina, na confluência dos Rios Tejipió, Jordão e Capibaribe, em Recife (SANTOS; KATO, 1997).

A área de estudo está situada na região conhecida como "Eixo do Desenvolvimento", entre as cidades de Recife e o Porto de Suape (Ipojuca - PE), tendo, dessa forma, grande potencial turístico (ainda não explorado), econômico e imobiliário. De acordo com levantamento feito pela Secretaria Estadual das Cidades, 35 mil pessoas vivem nas margens da lagoa e outras 150 mil num raio de até 2 quilômetros (FERNANDES, 2011).

A importância ambiental da Bacia do Olho d'Água e, consequentemente, o interesse na proteção da lagoa em si se deve, primeiramente, por ser ela a única área de restinga remanescente no estado. Nos últimos dez anos, entretanto, tem ocorrido uma forte pressão econômica e social, principalmente em função da ocupação crescente da área da bacia e mesmo no entorno da lagoa, para construção de moradias, conjuntos habitacionais e edifícios. Como consequência, muitos recursos naturais na bacia, tais como água, solo, fauna e flora nativas vêm se deteriorando, resultando em graves problemas de ordem sanitária-ambiental, de saúde pública e socioeconômicos (TENÓRIO, 2013). 


\section{Impactos ambientais na Lagoa Olho D’Água e o desafio do monitoramento ambiental em complexas áreas em processo de adensamento urbano}

Um dos grandes problemas enfrentados nos territórios nacional e estadual nos últimos tempos é a expansão urbana desordenada. Essa atividade prejudica não somente a qualidade de vida de todos os indivíduos como também impacta diretamente o meio ambiente, deixando a fauna e flora dos mais diversos biomas, e suas respectivas áreas de abrangência, reduzidas. Esse acelerado processo de urbanização das cidades brasileiras trouxe como consequência a ocupação de diversas áreas sem um planejamento adequado que minimizasse ou evitasse a degradação das áreas ocupadas (NOVAES, 2010).

Esse modelo de expansão urbana, de forma predatória, desordenada e não sustentável perdura ao longo da história brasileira, visto que a partir da revolução industrial as cidades, por não suportarem a grande migração do êxodo rural e não possuírem planejamento adequado, passaram a expandir suas áreas incondicionalmente. De acordo com Muller e Martine (1997), citados por Martins (2012): “O êxodo rural desencadeou uma intensa migração populacional rural-urbana, levando ao arranjo desordenado da população nas cidades até então existentes e/ou contribuindo para o surgimento de novos aglomerados populacionais".

Para Villaça (2001), é comum a ideia de que os os planos diretores devem "prever"as direções "para onde a cidade deve crescer" e em função disso devem ser criadas propostas.Contudo, é bastante comum identificar áreas em processo de expansão urbana sem o mínimo de planejamento adequado. De acordo com o Plano Diretor do município do Jaboatão dos Guararapes, são princípios norteadores desse plano:

I - a conservação e preservação do patrimônio natural e construído como suporte para o processo de desenvolvimento do município e a atribuição aos agentes públicos e privados da responsabilidade social pelas práticas ecológicas que venham a permitir, propiciar ou executar;

II - a diversidade urbanística que marca os seus distritos, como fator característico da identidade do município;

III - A importância fundamental dos espaços públicos para a vida da coletividade; IV - o direito à moradia digna;

V - os espaços institucionais com meio de manutenção de diálogo com a população;

VI - a preservação da capacidade de infiltração das bacias hidrográficas urbanas, para conservação ambiental dos cursos d'água e redução dos riscos de alagamentos e enchentes;

VII - a garantia do acesso universal aos bens e serviços urbanos e deslocamentos no espaço público, respeitado o direito dos portadores de necessidades especiais; VIII - A garantia do pleno desenvolvimento das funções sociais da cidade e da propriedade urbana. 
Sendo assim, o Plano Diretor de Jaboatão dos Guararapes (2008) prevê a preservação dos recursos naturais e visa ordenar o processo de uso e ocupação das terras a partir de uma série de princípios que pretendem proteger o direito da população a um meio ambiente preservado e à valorização do território.

No entanto, a própria dinâmica de acumulação capitalista culmina por determinar a forma de produção, apropriação e transformação dos espaços construídos. Porém, esse fundamento não avalia os possíveis impactos ao meio ambiente, tendo em vista que é levado mais em questão o crescimento populacional como fator predominante para a expansão urbana.Assim, a complexidade da ação dos agentes sociais produtores do espaço urbano, segundo Corrêa (2004, p. 11):

[...] inclui práticas que levam a um constante processo de reorganização espacial que se faz via incorporação de novas áreas ao espaço urbano, densificação do uso do solo, deterioração de certas áreas, renovação urbana, relocação diferenciada da infraestrutura e mudança, coercitiva ou não, do conteúdo social e econômico de determinadas áreas da cidade.

Segundo Martins (2012), o desenvolvimento ocorrido no Brasil, como fruto de políticas desenvolvimentistas, acarretou o crescimento acelerado das cidades brasileiras, cujo resultado tem sido uma configuração heterogênea destas. Esse processo acaba por não avaliar os riscos ambientais que por fim resultam em grandes impactos ao meio ambiente, como descreve Oliveira (2006), afirmando que o resultado do processo de intensa urbanização acarreta várias externalidades, tais como: poluição do ar e das águas, o lançamento de esgoto a céu aberto, favelização, ocupação de encostas e de áreas de risco.O efeito geral da urbanização vem sendo a intensificação de poluição urbana e isso tem afetado os recursos ambientais (GEHLEN, 2010).

Para Tenório (2013), a Lagoa Olho d'Água é considerada a maior lagoa no perímetro urbano do Brasil. No entanto, há um problema de gestão da paisagem desse ecossistema, necessitando ser compreendida dentro dos processos urbanos relacionados à paisagem. Embora fazendo parte desse cenário relacionado às atividades antrópicas de desvalorização e desequilíbrio ambiental, a Lagoa Olho d'Água faz parte do ecossistema estuarino do Rio Jaboatão, sendo fundamental dentro do ciclo hidrológico urbano, portanto, segundo o autor:

[...] sua relação com o urbano não está só vinculada à formação da cidade, mas está diretamente ligada às funções básicas que uma lagoa exerce dentro da ecologia urbana: amortização de cheias, recebimento das águas pluviais de uma bacia hidrográfica, amenização climática e atividades econômicas de subsistência. 


\section{O plano diretor, que abrange a Lagoa Olho d'Água, e sua importância na questão do desenvolvimento sustentável}

O conceito de desenvolvimento sustentável originou-se e assumiu importância em nível mundial a partir do relatório de Brundtland em 1987. Indicada pela ONU, a primeira-ministra da Noruega, Gro Harlem Brundtland, chefiou a Comissão Mundial sobre o Meio Ambiente e Desenvolvimento, para aprofundar propostas mundiais na área ambiental. A comissão foi criada em 1983, com o objetivo de promover audiências em todo o mundo e produzir um resultado formal das discussões. O documento final desses estudos foi intitulado "Nosso Futuro Comum" ou Relatório de Brundtland (FREITAS, 2013).

O documento passou a utilizar a expressão "desenvolvimento sustentável” definido como: "a forma como as atuais gerações satisfazem as suas necessidades sem, no entanto, comprometer a capacidade de as gerações futuras satisfazerem suas próprias necessidades" (COMISSÃO MUNDIAL SOBRE MEIO AMBIENTE E DESENVOLVIMENTO, 1988, p.46).

Para Brüseke (1998), o Relatório Brundtland:

[...] parte de uma visão complexa das causas dos problemas sócio-econômicos e ecológicos da sociedade global. Ele sublinha a interligação entre economia, tecnologia, sociedade e política e chama também atenção para uma nova postura ética, caracterizada pela responsabilidade tanto entre as gerações quanto entre os membros contemporâneos da sociedade atual (BRÜSEKE, 1998, p. 33).

O Relatório Brundtland também explica o conceito de desenvolvimento sustentável como “um processo de transformação no qual a exploração dos recursos, a direção dos investimentos, a orientação do desenvolvimento tecnológico e a mudança institucional se harmonizam e reforçam o potencial presente e futuro, a fim de atender às necessidades e aspirações humanas" (BRUNDTLAND, 1987).

No entanto, autores como Sobrinho (2008) destacam que a questão das necessidades na sociedade de consumo deixa evidente que qualquer tentativa de criação de modelos de sustentabilidade ambiental deveria passar "por uma radical transformação dos modelos econômicos e sociais, além da criação de uma nova moral e uma nova ética pautada pela preservação ambiental", o que não ocorre. Ao contrário, adotamos um modelo de desenvolvimento econômico que não rompe com o atual modelo de produção e, para o autor, pode se tornar "apenas uma falácia em relação à preservação ambiental”. 
Para Mendes (2008), no sentido de alcançar o desenvolvimento sustentável, a proteção do ambiente tem que ser entendida como parte integrante do processo de desenvolvimento e não pode ser considerada isoladamente. Desse ponto de vista, a ideia chave para o entendimento do desenvolvimento sustentável é a de que para ser alcançado ele dependerá do planejamento e do reconhecimento de que os recursos naturais são finitos (CARVALHO et al., 2015). Isso culmina na geração de conflitos pelo uso desses recursos, que se intensifica cada vez mais com o crescimento populacional, o aumento do consumo e o êxodo rural em direção às cidades, demandando bens e serviços que a administração pública não consegue prover, como já apontava a Comissão Mundial Sobre Meio Ambiente e Desenvolvimento (1988, p.266):

\begin{abstract}
Poucos governos das cidades do mundo em desenvolvimento, cujas populações crescem a um ritmo acelerado, dispõem de poderes, recursos e pessoal treinado para fornecer-lhes as terras, os serviços e os sistemas adequados a condições humanas de vida: água potável, saneamento, escolas e transportes. O resultado disso é a proliferação de assentamentos ilegais de habitações toscas, aglomerações excessivas e mortalidade desenfreada decorrente de um meio ambiente insalubre (COMISSÃO MUNDIAL SOBRE MEIO AMBIENTE E DESENVOLVIMENTO, 1988, p. 266).
\end{abstract}

E na tentativa de promover um novo padrão de desenvolvimento de forma mais sustentável, durante a Rio-92 foi institucionalizada a Agenda 21, que é um instrumento de planejamento para a construção de sociedades sustentáveis, em diferentes locais, que concilia métodos de proteção ambiental, justiça social e eficiência econômica, a partir da ideia de que o poder público e as comunidades locais, portanto em âmbito municipal, devem criar formas de promover o desenvolvimento com base na capacidade de "regeneração" do meio ambiente com ações de curto, médio e longo prazos para um determinado território (CONFERÊNCIA DAS NAÇÕES UNIDAS SOBRE MEIO AMBIENTE E DESENVOLVIMENTO, 1997; GOMES et al., 2014).

No entanto, Carvalho (2015) atenta para o fato de que aliar o desenvolvimento econômico com estratégias de conservação ambiental pode atingir resultados mais benéficos se houver incentivos econômicos para a conservação do meio ambiente, o que fundamentalmente passa por um planejamento, e este tem mais probabilidade de funcionar em nível local:

Para que uma sociedade seja sustentável, é necessário haver a integração do desenvolvimento com a conservação ambiental. A política econômica pode ser um eficaz instrumento para a sustentação dos ecossistemas e dos recursos naturais. $\mathrm{Na}$ falta de incentivos econômicos adequados, as políticas e as legislações que visam à proteção do meio ambiente e à conservação de recursos serão desconsideradas. Os sistemas convencionais costumam lidar com o meio ambiente e suas funções 
como sendo ilimitados ou gratuitos, dessa forma, incentivam a exaustão dos recursos e a degradação dos ecossistemas. (CARVALHO, 2015).

A agenda 21, em seu Capítulo 28, estabelece que "cada autoridade em cada país implemente uma Agenda 21 local tendo como base de ação a construção, operacionalização e manutenção da infraestrutura econômica, social e ambiental local, estabelecendo políticas ambientais locais e prestando assistência na implementação de políticas ambientais nacionais". Segundo o Ministério do Meio Ambiente (2017), como muitos problemas e soluções apresentados nesse documento têm suas raízes nas atividades locais, a participação e cooperação das autoridades locais são fatores determinantes para o alcance de seus objetivos (BRASIL, 2017).

Autores como Rodrigues (2001) relatam que é imprescindível a participação das autoridades locais para a elaboração de estratégias que impeçam, interrompam e revertam os efeitos da degradação ambiental, a fim de promover o desenvolvimento sustentável e ambientalmente saudável. Dessa forma, a Lei Federal no 10.257/2001, mais conhecida como Estatuto das Cidades, regulamenta os Artigos 182 e 183 da Constituição Federal e estabelece parâmetros e diretrizes da política e gestão urbana no Brasil, sendo uma obrigação legal de todos os municípios brasileiros com mais de 20 mil habitantes se dotarem de um Plano Diretor, conforme o Estatuto das Cidades (2001) no Art. 41 (BRASIL, 2001).

Nesse sentido, o Brasil tem muitos problemas que poderiam ser solucionados através de um Plano Diretor adequado às especificidades de determinadas áreas, tais como: "o crescimento demográfico desordenado, a especulação imobiliária, habitações subnormais e em zonas de risco, degradação ambiental, dentre outras”. Dessa forma, é o plano territorial que identifica a natureza dos espaços e define suas destinações, inclusive os seus usos futuros. Portanto, pode solucionar e mesmo prevenir vários desses problemas (BRASIL, 2005).

No Art. 10 do Capítulo II do Plano Diretor do município de Jaboatão dos Guararapes que trata das diretrizes gerais para conservação do Patrimônio Ambiental, nota-se a tentativa do município de conter o crescimento urbano acelerado e a ênfase na proteção do meio natural. Dessa forma, as diretrizes que tratam do assunto citam:

I - a proteção, com áreas verdes, das margens e leitos expandidos de rios e lagoas, proibindo a construção, nessas áreas, de imóveis destinados tanto ao uso residencial como industrial comercial e serviços;

II - a proteção, recuperação e conservação de recursos naturais, tais como mananciais, matas, mangues, restingas, cursos d'água, estuários e outros de reconhecido interesse ambiental para o Município e de importância estratégica para as gerações futuras [...]. 
Dessa forma, vemos contempladas no Plano Diretor do município as lagoas localizadas no âmbito de atuação do poder público municipal, e em especial a Lagoa Olho d'Água (também chamada Lagoa do Náutico). Já na Seção II, Art.13, o Plano Diretor sobre o sistema de esgotamento sanitário trata diretamente sobre a Lagoa Olho d’Água: "III - proibição do lançamento de esgotos, não tratados, na bacia de drenagem da Lagoa do Náutico".

No Art. 31, o Plano Diretor tratada Zona de Adensamento Construtivo Baixo (ZAB), na qual predominam áreas alagáveis e ocupações irregulares. Neste artigo, o Plano Diretor destina-se ao reordenamento da ocupação atual e crescimento urbano condicionados às restrições de drenagem, oferta de infraestruturas e ao atendimento das seguintes diretrizes:

\footnotetext{
[...]

III - regularização fundiária das Zonas Especiais de Interesse Social (ZEIS) e outras áreas de pobreza que apresentem condições precárias de estabilidade e salubridade, com reassentamento de ocupações de risco, com interferência na proteção ambiental da Lagoa do Náutico;

IV - contenção do adensamento construtivo;

V - valorização ambiental e paisagística da Lagoa do Náutico, com aproveitamento do seu potencial turístico e de lazer.
}

No Art. 33, o Plano destaca a Zona de Qualificação Urbana (ZQU), dividida em três segmentos, dentre eles, a Lagoa do Náutico:

I- ZQU 1, área entre a BR-101 antiga e a Lagoa do Náutico para a qual são estabelecidas as seguintes diretrizes:
a) eliminação da situação de risco de alagamentos a que está sujeita;
b) priorização de investimentos para melhorar a infraestrutura;
c) contenção do adensamento construtivo;
d) promoção da urbanização e da regularização fundiária;
e) promoção da acessibilidade e da mobilidade.

Segundo o Art. 91, que trata do Projeto de controle do uso e ocupação do solo nas áreas sujeitas a alagamento terá por ações:

I - intensificação da fiscalização para impedir aterro e ocupação irregular das áreas sujeitas a alagamento aplicando as diretrizes e parâmetros urbanísticos do Plano Diretor de drenagem urbana;

II - fiscalização e monitoramento da atividade de extração mineral nas áreas alagáveis;

III - ocupação com vegetação nativa da área não edificável em torno da Lagoa do Náutico e das áreas de preservação permanente dos cursos d'água que drenam as planícies flúvio-lagunar e aluvional; 
IV - criação de áreas verdes, de uso coletivo, em espaços com potencial para alagamentos eventuais;

$\mathrm{V}$ - minimização do uso de condutos e de canalização de rios para recuperar a condição de drenagem urbana.

VI - estabelecimento na lei de uso do solo de cotas mínimas de projeto de construção.

No Art. 92 do Plano Diretor há o projeto de recuperação e preservação dos recursos hídricos superficiais, que tem por ações:

I - ocupação, com vegetação preferencialmente nativa, das áreas de preservação permanente, dos rios e reservatórios artificiais localizados fora do perímetro urbano;

II - ordenamento e controle da ocupação das margens de rios e reservatórios localizados no perímetro urbano;

III - recuperação da qualidade da água da Lagoa do Náutico e dos rios Jaboatão, Tejipió e respectivos tributários;

IV - fiscalização contínua para inibir a extração de areia no leito dos rios.

O Art. 95 trata do Programa de Sistema de Parques e Espaços Verdes, que objetiva oferecer espaços naturais de importância ambiental, de forma sustentável, para o lazer e atividades recreativas consoante com os seguintes projetos e ações:

I - utilização das margens do Rio Jaboatão, elemento marcante da identidade municipal, para o lazer e recreação, e integrando-o visualmente e funcionalmente à paisagem existente;

II - projeto de Sistema de Áreas Livres que avalie perímetros, demandas e público, associado à negociação com agentes privados para viabilizar a implementação ou a conservação de equipamentos prioritários;

III - requalificação e implantação de parques e espaços públicos com incentivo à visitação;

IV- recuperação, ampliação e criação de áreas verdes e lazer em assentamentos populares e conjuntos habitacionais.

Considerando que a diretriz estabelecida no Inciso III deve levar em conta os espaços potenciais do Parque da Lagoa do Náutico (JABOATÃO DOS GUARARAPES, 2008).

Utilização do sensoriamento remoto no monitoramento dos recursos ambientais em relação aos impactos antrópicos sobre o meio ambiente

O sensoriamento remoto (SR) é definido de diferentes maneiras por diversos autores. Segundo Avery e Berlin (1992) e Meneses (2001) ele é: "Uma técnica para obter informações sobre 
objetos através de dados coletados por instrumentos que não estejam em contato físico como os objetos investigados". Para Jensen (2009), o sensoriamento remoto pode ser definido como a arte e a ciência de obter informações sobre objetos, sem que haja contato físico direto com eles.

O sensoriamento remoto também pode ser definido como sendo a utilização conjunta de modernos sensores, equipamentos de transmissão de dados, equipamentos para processamento de dados, aeronaves e espaçonaves que têm como objetivo o estudo das interações no ambiente terrestre, sem o contato físico direto com as feições, entre a radiação eletromagnética e as substâncias componentes do planeta Terra em suas diversas manifestações (NOVO, 2008).

O desenvolvimento das técnicas de sensoriamento remoto tem permitido a aquisição de diversas informações sobre a superfície terrestre, dando suporte às análises temporais, edáficas e fenológicas da vegetação (VINAGÓ et al., 2011). Pereira et al. (1989) citam que o levantamento do uso atual da terra, necessário para fins de planejamento, pode ser obtido a partir da utilização de dados multiespectrais, fornecidos por satélites de sensoriamento remoto, associados às técnicas de interpretação.

Para perceber mudanças ocorridas em determinado ambiente, faz-se necessária a utilização de imagens de satélites oriundas de diferentes datas, obtendo-se assim uma análise multitemporal. Os trabalhos que abordam a análise multitemporal com imagens de satélite cada vez mais se intensificam, servindo para o monitoramento do crescimento urbano, bem como para a análise da evolução do desmatamento, da urbanização e extensão agrícola, entre outros (CARVALHO JÚNIOR et al., 2005).

Conforme indicam estudos aplicados sobre sensoriamento remoto, a maioria dos trabalhos realizados nas últimas décadas tem focado os ambientes naturais, sendo que as aplicações dessas tecnologias nas áreas urbanas são relativamente recentes (WENG; QUATTROCHI, 2006; MELESSE et al., 2007).

Segundo Freitas (2008), o sistema clima-urbano é um sistema aberto e dinâmico em que os seus elementos (temperatura, umidade, pluviosidade e ventilação) são modificados constantemente, principalmente por fatores antrópicos locais tais como: morfologia urbana, corredores de vento, tráfego de veículos, atividades industriais, aterros, entre outros. Isso contribui para a formação de microclimas no ambiente urbano.

Com o advento de imagens de média e alta resolução e técnicas mais robustas, o sensoriamento remoto tem sido muito utilizado para mapear os tipos de uso e cobertura da terra e para a detecção dos elementos que compõem o espaço intraurbano. No caso do mapeamento do uso e da cobertura da terra, as imagens de satélite permitem adquirir e explorar alguns dados e 
informações para a análise de qualidade ambiental, que podem subsidiar o planejamento e a gestão territorial. O nível de detalhe e a precisão obtida dependerão das características dos sensores orbitais, das técnicas utilizadas no processamento das imagens, além do conhecimento da área de estudo (CARDOSO; AMORIM, 2014).

Em contrapartida, para automatizar o processo de mapeamento da superfície terrestre a partir da resposta espectral única dos diferentes alvos a uma determinada região do espectro eletromagnético, combinações apropriadas entre as bandas das imagens de satélite têm servido de base ao desenvolvimento de um conjunto de índices radiométricos que procuram discriminar os principais tipos de uso e cobertura da terra (ZHA et al., 2003; PINHEIR; LARANJEIRA, 2013).

Os índices radiométricos são medidas capazes de identificar e realçar em imagens de satélites determinados tipos de informações, tais como áreas edificadas, cobertura vegetal, cursos d'água, solo exposto, entre outros, além da normalização contribuir na redução de ruídos e efeitos de iluminação (FRANÇA et al., 2012).

De acordo com Ponzoni (2001), a aparência da cobertura vegetal em determinado produto de sensoriamento remoto é fruto de um processo complexo que envolve muitos parâmetros e fatores ambientais. Autores como Silva et al. (2011) e Silva et al. (2015) salientam que o que é efetivamente medido por um sensor remotamente situado, oriundo, por exemplo, de determinada vegetação (alvo), não pode ser explicado somente pelas características intrínsecas dessa vegetação; inclui também a interferência de vários outros parâmetros e fatores, tais como: a fonte de radiação, o espalhamento atmosférico, as características tanto das folhas quanto do dossel, os teores de umidade do solo, a interferência da reflectância do solo, sombra, entre outros.

A utilização de índices de vegetação como o Índice de Vegetação da Diferença Normalizada (NDVI) e o Índice de Vegetação Ajustado ao Solo (Savi) facilitam a obtenção e modelagem de parâmetros biofísicos das plantas, como a área foliar, biomassa e porcentagem de cobertura do solo, com destaque para a região do espectro eletromagnético do infravermelho, que pode fornecer importantes informações sobre a evapotranspiração das plantas (JENSEN, 2009; EPIPHANIO et al., 1996).

A modelagem dos índices de vegetação baseia-se no comportamento oposto da refletância da vegetação na região do visível, ou seja, quanto maior a densidade vegetal, menor é a refletância em função da absorção da radiação pelos pigmentos fotossintetizantes e quanto maior a densidade vegetal, maior a refletância devido ao espalhamento nas diferentes camadas das folhas (BORATTO; GOMIDE, 2013). 
Os índices são apontados como indicadores de crescimento e vigor da vegetação e podem ser utilizados para diagnosticar vários parâmetros biofísicos com os quais apresentam altas correlações, incluindo o índice de área foliar, biomassa, porcentagem de cobertura do solo, atividade fotossintética e produtividade (PONZONI; SHIMABUKURU, 2001). Esses índices têm sido utilizados com sucesso para o monitoramento de mudanças na vegetação em escala regional, continental e global (BARBOSA, 2006).

Dessa forma, o objetivo deste trabalho é analisar a transformação da natureza e as potencialidades do monitoramento ambiental na Lagoa Urbana Olho d'Água - PE, considerando os desafios existentes na relação, muitas vezes, antagônica entre desenvolvimento urbano e a conservação de ambientes naturais, a partir da análise espaço-temporal da área de estudo com base nos índices de vegetação NDVI e Savi, aplicados em imagens de satélite do Landsat-5 sensor TM.

Com isso, o trabalho buscará elaborar produtos que possam ser utilizados para diversos fins, tais como o monitoramento do crescimento da área urbana e a dinâmica da vegetação na área. Esses mapeamentos poderão servir de base para o planejamento ambiental urbano e para a elaboração de estratégias de gestão ambiental para a resolução das diversas externalidades decorrentes do adensamento urbano sobre os ecossistemas naturais.

\section{Materiais e método}

\section{Análise espaço-temporal}

Inicialmente realizou-se a delimitação da área estudada. As imagens foram colocadas na projeção UTM, Datum WGS 1984. Foram interpretadas e analisadas imagens das datas de 10-07-1989, 09-08-2000 e 06-09-2010 do satélite Landsat-5, disponibilizadas gratuitamente no portal eletrônico oficial do Instituto Nacional de Pesquisas Espaciais (Inpe) e processada no laboratório de Sensoriamento Remoto e Geoprocessamento (Sergeo) da UFPE, que detém a licença dos softwares ArcGis 9.2 e Erdas Imagine 9.2 utilizados neste trabalho.

\section{Calibração radiométrica}

A metodologia adotada é a mesma utilizada pelos autores Silva et al. (2011), Silva et al. (2015) e mais recentemente por Melo et al. (2017), em que o conjunto da radiância ou calibração radiométrica é obtido utilizando-se a equação proposta por Markham e Baker (1987), (Equação 1):

$$
L \lambda \mathrm{i}=\alpha \mathrm{t}+\frac{\mathrm{bt}-\mathrm{at}}{255} \mathrm{ND}
$$


Em que a e b são as radiâncias espectrais mínima e máxima (1 $12 \mu \mathrm{m}$ srWm), ND é a intensidade do pixel (número inteiro compreendido entre 0 e 255) e i corresponde às bandas $(1,2, \ldots$ e 7) do satélite Landsat 5 e 7. Os coeficientes de calibração utilizados para as imagens TM são os propostos por Chander e Markham (2003) e Oliveira et al. (2010).

\section{Reflectância}

A reflectância de cada banda (i) é definida como a razão entre o fluxo de radiação solar refletido pela superfície e o fluxo de radiação solar global incidente, obtida através da equação (ALLEN et al., 2002 apud OLIVEIRA et al., 2010), (Equação 2):

$\rho \lambda \mathbf{i}=\frac{\pi \cdot L \lambda i}{K \lambda i \cdot \cos \mathrm{Z} \cdot \mathrm{dr}}$

Em que $\lambda \mathrm{iL}$ é a radiância espectral de cada banda, $\lambda \mathrm{iK}$ é a irradiância solar espectral de cada banda no topo da atmosfera $12 \mu \mathrm{m}, \mathrm{Z}$ é o ângulo zenital solar e rd é o quadrado da razão entre a distância média Terra-Sol (ro) e a distância Terra-Sol (r) em dado dia do ano (DSA) (OLIVEIRA et al., 2010; SILVA et al., 2011).

\section{Normalized Difference Vegetation Index (NDVI)}

O Índice de Vegetação da Diferença Normalizada (NDVI) foi obtido através da razão entre a diferença das refletividades do infravermelho próximo ( $\rho \mathrm{IV})$ e do vermelho $(\rho \mathrm{V})$ e a soma entre elas. Segundo Rosendo (2005), quanto mais próximo de 1 estão os valores de NDVI, mais densa é a vegetação; já o valor 0 (zero) ou menor que 0 indica uma superfície não vegetada. Os maiores valores de NDVI correspondem aos Números Digitais (ND) mais elevados, que se relacionam às áreas de vegetação com maior vigor. Enquanto os menores valores equivalem aos ND baixos, representando as áreas de vegetação estressada, bem menos densas ou até mesmo áreas desnudas (SILVA et al., 2015) (Equação 3):

$(\mathrm{IVP}-\mathrm{V}) /(\mathrm{IVP}+\mathrm{V})(3)$

\section{Índice de Vegetação - Soil Adjusted Vegetation Index (Savi)}

O Savi (Equação 4) foi desenvolvido por HUETE (1988), sendo uma técnica de transformação para minimizar a influência da reflectância do solo nos índices de vegetação espectrais que envolvem os comprimentos de onda do vermelho e infravermelho próximo e 
modelar, com mais precisão, a radiância infravermelha próxima nas copas mais abertas (SILVA et al., 2011), (Equação 4):

Savi $=\frac{(1+L)(\rho I V-\rho V)}{(L+\rho I V+\rho V}$

\section{Resultados e discussão}

O NDVI estima o conteúdo de clorofila (pigmento esverdeado) presente na vegetação, sendo assim, o NDVI irá identificar a vegetação sadia nos anos de 1989, 2000 e 2010 (Figura 1). 


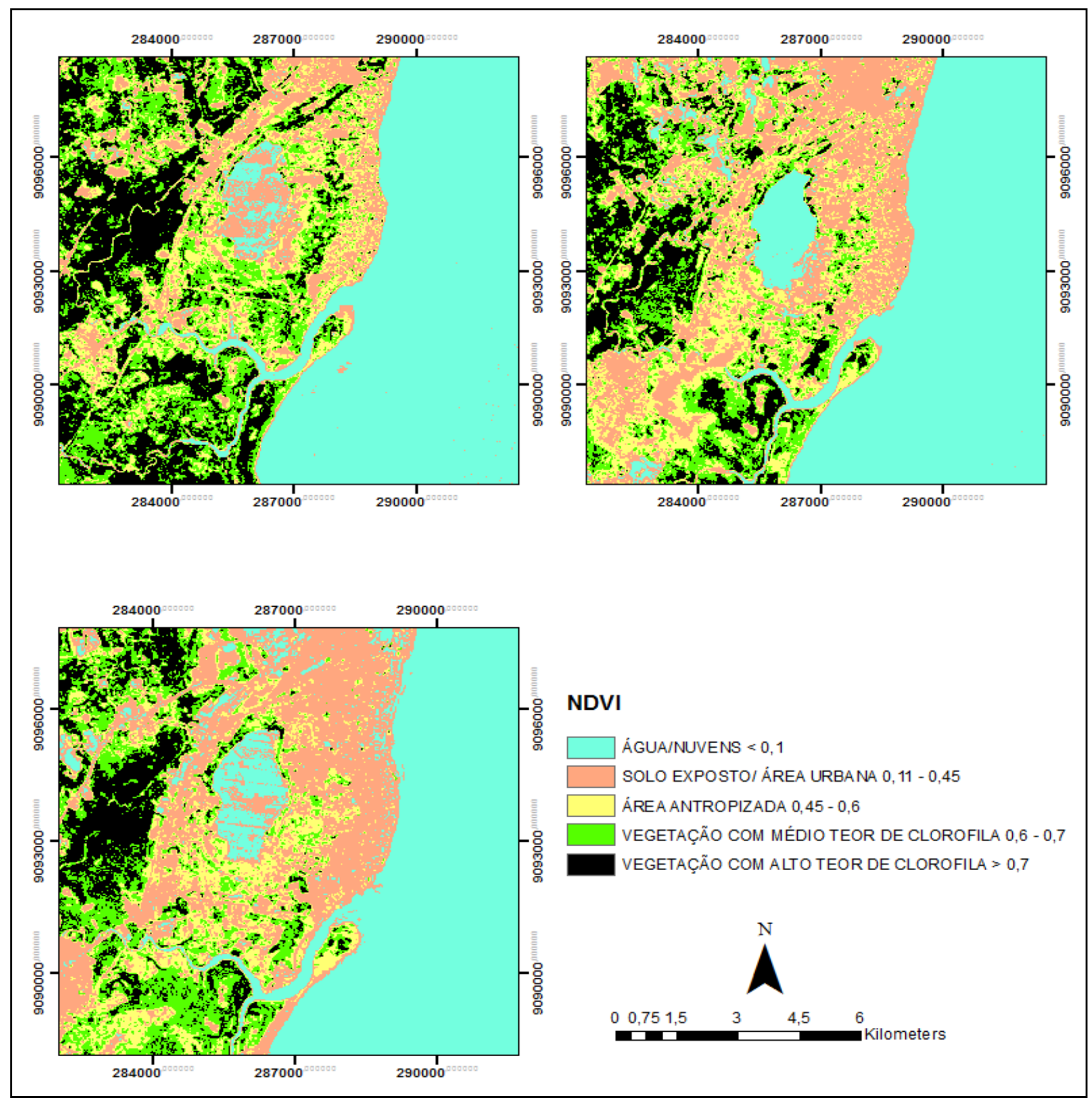

FIGURA 1 - CONTEÚDO DE CLOROFILA NA VEGETAÇÃO DA LAGOA OLHO D’ÁGUA

FONTE: Elaborado pelos autores.

Dessa forma, observou-se que o NDVI menor que 0,1 correspondeu à presença de nuvens e água na Figura 1. Durante os anos houve uma diminuição das áreas verdes ao redor da Lagoa Olho d'Água; em contrapartida, as áreas urbanas aumentaram em densidade, ocupando espaços que anteriormente eram áreas vegetadas, o que pode ser constatado pelo aumento da mancha urbana e diminuição do teor de clorofila na vegetação (NDVI < 0,45). As áreas antropizadas, nos 3 anos analisados na Figura $1(0,45-0,6)$, foram aquelas que, apesar de estarem sendo pressionadas pelo adensamento urbano em volta, ainda apresentam certa área de vegetação. 
A vegetação com considerável teor de clorofila, em duas décadas, apresentou uma considerável diminuição do ano de 1989 até 2010. As áreas com predominância dos valores que vão de 0,6-0,7 são justamente aquelas que se distanciam mais da área litorânea em direção ao interior. O mesmo padrão foi encontrado na vegetação com alto teor de clorofila (NDVI > 0,7), que na década de 1980 apresentava certa predominância na área na década de 1980.

Jensen (2009) apresenta alguns pontos positivos e negativos na utilização do NDVI. Para esse autor, a importância desse índice concentra-se em dois aspectos 1) o monitoramento de mudanças sazonais e interanuais da atividade e do desenvolvimento da vegetação e 2) a redução de ruídos, como sombras de nuvens, variações topográficas e diferença de iluminação solar. Como foi visto na Figura 1, esse índice foi útil para demonstrar as variações do vigor vegetativo ao longo dos anos.

Deve-se salientar que a área que se apresenta com maior teor de clorofila é justamente a que pertence, segundo o Plano Diretor do município de Jaboatão dos Guararapes (2008), à Zona de Proteção Estuarina (ZPE). Segundo o Art. 49 do Plano Diretor do município de Jaboatão dos Guararapes, a Zona de Proteção Estuarina compreende as áreas estuarinas dos Rios Jaboatão e Pirapama constituídas por manguezais ou restingas, e tem por objetivo a conservação desses ambientes. Essa área é uma das Zonas Especiais, distribuídas nas macrozonas em que se divide o território municipal, distinguindo-se das demais zonas por possuírem características especiais que demandam tratamento específico, segundo o Art. 41 do Plano Diretor.

Por essa razão, no Art. 10, Caput 2, o Plano Diretor de 2008 enfatiza a proteção, com áreas verdes, das margens de lagoas como a Olho d’Água, proibindo a construção, nessas áreas, de imóveis destinados tanto ao uso residencial como industrial, comercial e serviços, dando ênfase à proteção, recuperação e conservação de recursos naturais, tais como mananciais, matas, mangues, restingas, cursos d'água, estuários e outros de reconhecido interesse ambiental para o município. No entanto, visualiza-se o intenso crescimento urbano ocorrido não só no ano de 1989 e 2000, mas também no ano de 2010, como visualizado na Figura 1, com aumento da presença de áreas de solo exposto e/ou área urbana (valores de 0,11 a 0,45), portanto, após a elaboração do Plano Diretor.

Também foi utilizado para analisar espaço-temporalmente a área um índice que leva em conta o ajuste em relação ao solo (Savi). Esse índice tem potencial para evidenciar as manchas de solo exposto presentes na área e a degradação presente em algumas áreas, já que é um dos componentes constituintes do índice de área foliar (IAF), e este, por conseguinte, é influenciado pela biomassa presente na área. Dessa forma, o resultado do Savi apresenta-se a seguir (Figura 2): 


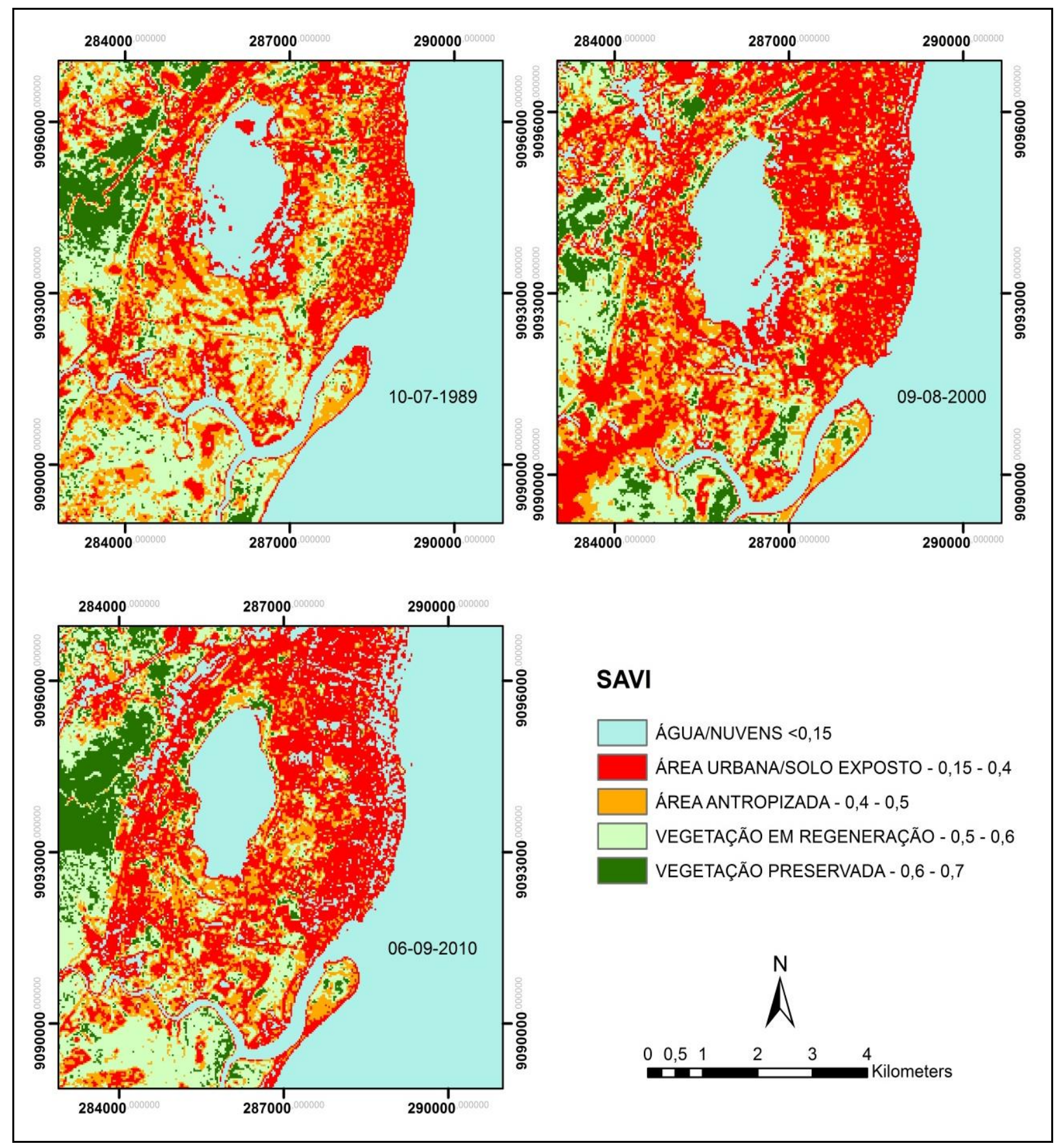

FIGURA 2 - CONTEÚDO DE VEGETAÇÃO À ALTURA DO SOLO DA LAGOA OLHO D’ÁGUA FONTE: Elaborado pelos autores.

Na Figura 2 fica claro o padrão de urbanização ao redor da Lagoa Olho d'Água e como esta tem se apresentado como principal tensionador na área. As áreas verdes ainda presentes na área correspondem às áreas de proteção ambiental como a Zona de Proteção Estuarina prevista no Plano Diretor do município de Jaboatão dos Guararapes. 
Como pode ser visualizado na Figura 2, as imagens de 2000 e 2010 apresentaram um maior adensamento urbano em relação ao ano de 1989. As áreas antropizadas também apresentaram crescimento em relação ao final da década de 1980. Já a vegetação preservada (Savi > 0,6) apresentou crescimento apenas na área correspondente à Zona de Proteção Estuarina, já que o Plano Diretor prioriza a proteção dessa área. Nas demais áreas, o processo de adensamento urbano levou à diminuição da vegetação.

Dessa forma, o Savi foi útil para o monitoramento da dinâmica da vegetação ao longo das últimas décadas, tornando evidente as modificações ocorridas em função do crescimento urbano sobre áreas naturais, devido a esse índice destacar melhor as áreas de solo exposto na região de estudo em relação ao NDVI. Esse tipo de comportamento é esperado, como observam Gilabert et al. (2002) e Eastman (2006), pois o índice de vegetação ajustado ao solo (Savi) procura minimizar os efeitos da reflectância do solo ao considerar a incorporação de um fator de ajuste dependente da densidade de vegetação.

Nesse sentido, tem se intensificado a preocupação sobre formas de controle que mitiguem a degradação ambiental, o que passa pelo prévio planejamento das formas de utilização da terra. O levantamento do uso atual da terra, necessário para fins de planejamento, pôde então ser obtido a partir da utilização de dados multiespectrais, fornecidos por satélites de sensoriamento remoto neste trabalho.

Autores como Leal (2002) já alertavam para o fato da modificação de parâmetros da vegetação na lagoa estar ocorrendo, registrando as diferenças entre as formações vegetacionais encontradas no início da década de 2000 e as identificadas nos estudos da década de 1960, devido ao processo de antropização nos arredores desse ecossistema. Segundo o Relatório Ambiental Preliminar dos Estudos de Impactos Ambientais do projeto de macrodrenagem da Lagoa Olho d'Água da Empresa Municipal de Desenvolvimento de Jaboatão dos Guararapes (EMDEJA, 2003), a fauna presente nela e nos arredores é caracterizada por espécies ajustadas às condições urbanas ou de ambientes próximos das ocupações, ou seja, sua paisagem é ao mesmo tempo natural e urbana.

Como agravante, o mesmo Plano Diretor municipal que dá ênfase à conservação ambiental da Lagoa Olho d'Água é o mesmo que prevê criações de vias e aumento do fluxo de transporte nas áreas próximas à Lagoa Olho d'Água (também chamada Lagoa do Náutico) para criação de novas dinâmicas urbanas, como fala o Art. 117 do Plano Diretor que trata do Programa de Acessibilidade Sustentável, que tem por objetivo garantir integração viária e transporte público de qualidade, intradistritos e interdistritos, e oferecer condições de circulação segura aos ciclistas, pedestres, inclusive idosos e portadores de necessidades especiais através dos projetos e ações a seguir: 
III - implantação da via metropolitana sul, à leste da Lagoa do Náutico;

IV - implantação da via de contorno da Lagoa do Náutico, em sua face oeste;

V - implantação de sistema de binários nas vias de ligação da Lagoa do Náutico com a faixa de praia, criando faixas exclusivas para ciclistas.

Dentre as Vias Arteriais propostas no Plano Diretor está a Via Metropolitana Sul, que segundo o Plano, "margeia a linha sul do metrô desde o limite Recife/Jaboatão dos Guararapes, até a Estação Cajueiro Seco, onde inflete no sentido leste contornando a Lagoa do Náutico de onde muda a sua diretriz até encontrar a BR-101 (antiga) após Pontezinha”.

Dessa forma, fica clara a relação, muitas vezes conflituosa, entre o desenvolvimento urbano e a conservação de ambientes naturais. Ao mesmo tempo em que o Plano Diretor prevê a conservação da Lagoa Olho d'Água, existem vários projetos de melhoramento de acessibilidade para atração de empreendimentos para a área, principalmente empreendimentos imobiliários como o "Praia de Piedade Condomínio Clube" da construtora MRV Engenharia, com 864 apartamentos, construído mais recentemente e voltados para a população de classe média, empreendimentos esses que contrastam com empreendimentos mais antigos. Segundo Tenório (2013), as ocupações no entorno da lagoa são voltadas para a população de baixa renda, com moradias sem infraestrutura adequada. Com a ação do mercado imobiliário e os programas de habitação social foram construídos alguns conjuntos residenciais (Figura 3):
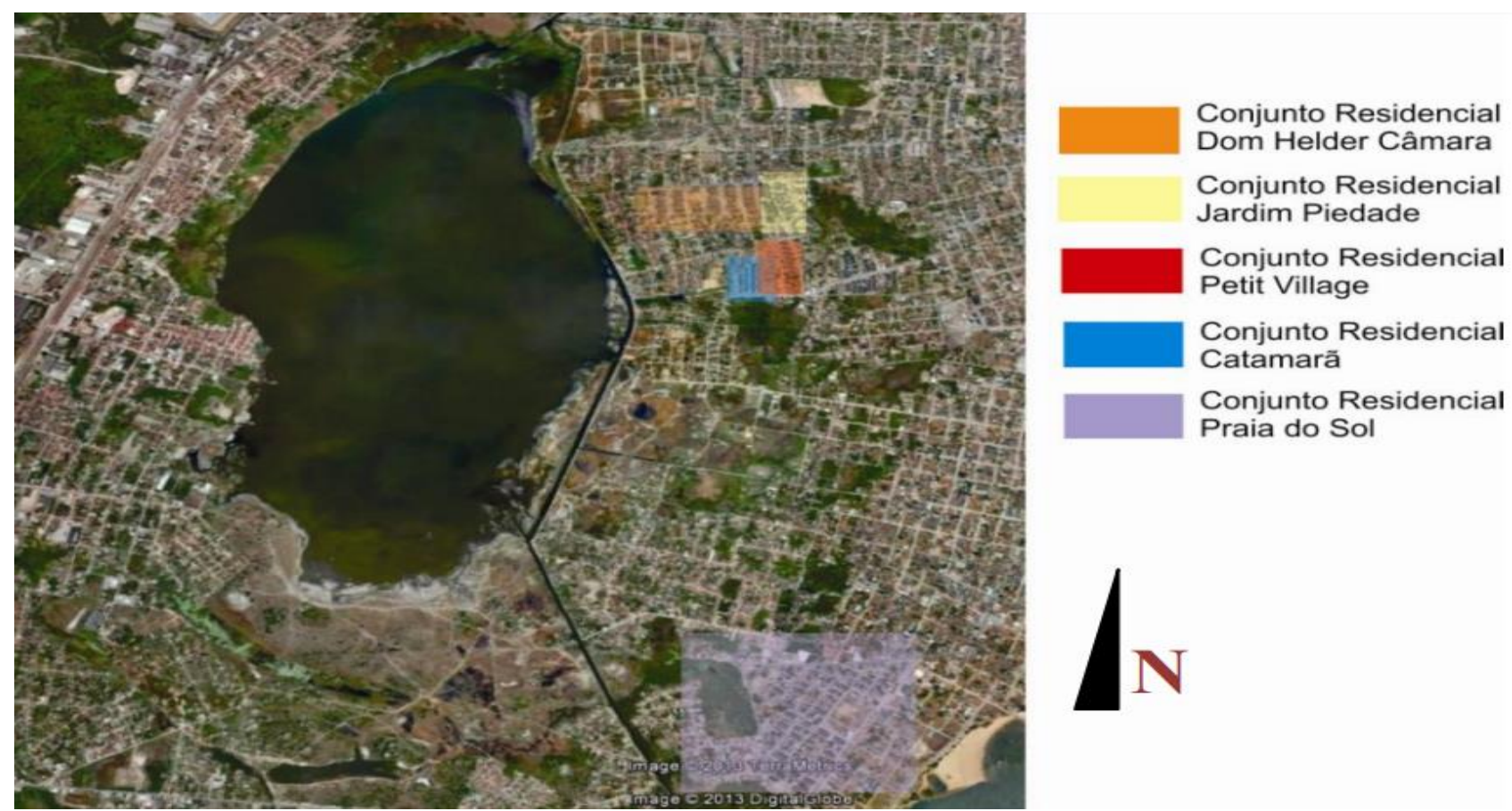

FIGURA 3 - CONJUNTOS RESIDENCIAIS NO ENTORNO DA LAGOA OLHO D’ÁGUA FONTE: TENÓRIO (2013). 
Ainda segundo Tenório (2013), diante do acelerado crescimento econômico vivido pelo estado de Pernambuco nos últimos anos, mais especificamente na região portuária de Suape, o município de Jaboatão dos Guararapes "foi alvo de impactos tanto econômica quanto fisicamente com a pressão urbana decorrente dos fortes investimentos na economia local e no mercado imobiliário". Além da disponibilidade de terrenos para novas construções, principalmente na parte oeste, nas proximidades da Lagoa Olho d'Água nos bairros de Piedade e Candeias, há facilidade de acesso à Suape através da Ponte do Paiva e proximidade com a cidade do Recife.

Dessa forma, nota-se a relação complexa entre o desenvolvimento urbano e a conservação de ambientes naturais. Por um lado, o Plano Diretor prevê diretrizes e estratégias de preservação ambiental para a Lagoa Olho d'Água e, por outro, prevê projetos que intensificarão a urbanização da área, pois com os projetos de construção dos eixos viários previstos haverá, consequentemente, a atração de mais empreendimentos para a área.

Por essa razão, Souto (2006) e Hanazaki et al. (2010) afirmam que a conexão entre biodiversidade e sociedade não é uma mera coexistência, mas sim uma retroalimentação entre esses dois elementos, em que a biodiversidade pode atuar na construção da sociedade e esta, por sua vez, pode atuar na manutenção da biodiversidade.

Portanto, este trabalho possibilitou a identificação dos principais tensores na Lagoa Olho d'Água - PE (sendo a expansão urbana e a especulação imobiliária os maiores), bem como demonstrou a intensidade da degradação do ambiente natural ao longo das últimas décadas de período amostral. Nesse sentido, a relação conflituosa entre desenvolvimento urbano e conservação dos componentes naturais fica evidenciada através da utilização de ferramentas de sensoriamento remoto e esses produtos podem servir como base para o planejamento e gestão ambiental para conservação da natureza, mas especialmente pela manutenção dos serviços ambientais prestados por esses ecossistemas.

\section{Conclusão}

Os resultados obtidos com a utilização de sensores remotos e técnicas de processamento de imagens demonstraram que a Lagoa Olho d'Água sofre um processo intenso de adensamento urbano nos últimos 20 anos sobre áreas naturais ambientalmente frágeis, fazendo com que haja a preocupação acerca dos limites do desenvolvimento urbano. 
Os resultados demonstrados pelo trabalho contribuem para a discussão acerca da apropriação do espaço e de como os componentes naturais vêm sendo utilizados na área de estudo. Esses resultados podem servir para o planejamento de estratégias de proteção e conservação do ambiente e para a gestão e o monitoramento ambiental contínuo da Lagoa Olho d'Água.

\section{Referências}

ALLEN, R.; TASUMI, M.; TREZZA, R. SEBAL (Surface Energy Balance Algorithms for Land). Advanced Training and User's Manual - Idaho Implementation, version 1.0. 2002.

ARANA, A. R. A.; FROIS, M. R. Planejamento urbano ambiental: diretrizes para o zoneamento na bacia do córrego do Limoeiro em Presidente Prudente-SP. Geousp - Espaço e Tempo (On-line), v. 20, n. 3, p. 619-635, 2016. ISSN 2179-0892.

ASSIS, H. M. B. de. Projeto diagnóstico do meio físico da bacia da Lagoa Olho d'Água. Recife: CPRM/PMJG, 1997.

ASSIS, D. R. S.; PIMENTEL, R. M. M.; CASTILHO, C. J. M. Impactos da urbanização e vulnerabilidade de lagoas costeiras. Revista Brasileira de Geografia Física, v. 06, n. 02, p.223-232, 2013.

AVERY, T. E.; BERLIN, G. L. Fundamentals of remote sensingand airphoto interpretation. 5. ed. New Jersey: Prentice Hall, 1992.

BAPTISTA NETO, J. A.; SILVA, C. G.; DIAS, G. T. de M.; FONSECA, E. M. da. Distribuição sedimentar da Lagoa Rodrigo de Freitas através de sísmica de alta resolução. Revista Brasileira de Geofísica, v.29, n.1, p.187-195, 2011.

BARBOSA, K. M. do N. Monitoramento espacial de biomassa e carbono orgânico da vegetação herbácea de várzea na Amazônia Central. Curitiba: Universidade Federal do Paraná, Tese de Doutorado, 131 p., 2006.

BARROSO, V. L., MEDINA, R. S., MOREIRA-TURQ, P. F., BERNARDES, C. M. Aspectos ambientais e atividades de pesca em lagoas costeiras fluminenses. Série Meio Ambiente em Debates, 31. Instituto Brasileiro do Meio Ambiente e dos Recursos Naturais Renováveis, Diretoria de Gestão Estratégica - Brasília. Ed. Ibama, 50p., 2000.

BORATTO, I. M. de P.; GOMIDE, R. L. Aplicação dos índices de vegetação NDVI, Savi e IAF na caracterização da cobertura vegetativa da região Norte de Minas Gerais.Anais XVI Simpósio Brasileiro de Sensoriamento Remoto - SBSR, Foz do Iguaçu, PR, Brasil, 13 a 18 de abril de 2013, Inpe. 
BRASIL. Código Florestal, Lei $\mathbf{n}^{0}$ 12.727, de 17 de outubro de 2012. Disponível em: <http://www.planalto.gov.br/ccivil_03/_ato2011-2014/2012/lei/112727.htm . Acesso em: 2 jun. 2017.

BRASIL.Código Florestal,Lei $\mathbf{n}^{\mathbf{0}}$ 12.651, de 25 de maio de 2012. Disponível em: <http://www.planalto.gov.br/ccivil_03/_ato2011-2014/2012/lei/112651.htm >. Acesso em:18set. 2017.

BRASIL. Constituição da República Federativa do Brasil. Constituição (1988). Disponível em: <http://www.planalto.gov.br/ccivil_03/constituicao/Constituicao.htm\#art171 >. Acesso em: 11 set. 2017.

BRASIL. Decreto $\mathbf{n}^{\circ}$ 6.678, de 8 de dezembro de 2008. Aprova o VII Plano Setorial para os Recursos do Mar. Disponível em: <http://www.planalto.gov.br/ccivil_03/_Ato20072010/2008/Decreto/D6678.htm $\geq$. Acesso em: 19 set. 2017.

BRASIL. Lei Federal $\mathbf{n}^{\mathbf{0}}$ 10.257, de 10 de julho de 2001. Estatuto das Cidades. Disponível em: <http://www.planalto.gov.br/ccivil_03/leis/LEIS_2001/L10257.htm_. Acesso em: 23jul.2017.

BRASIL. Lei Federal $n^{0}$ 6.938, de 31 de agosto de 1981. Dispõe sobre a Política Nacional do Meio Ambiente, seus fins e mecanismos de formulação e aplicação, e dá outras providências. Diário Oficial da República Federativa do Brasil. Brasília, 02 set. 1981. Disponível em: <http://www.planalto.gov.br/ccivil_03/leis/L6938.htm z. Acesso em: 11set. 2017.

BRASIL. Ministério das Minas e Energia. CPRM - Serviço Geológico do Brasil. Projeto Diagnóstico do meio físico da Bacia Olho d'Água. Recife, 94 p., 1997.

BRASIL. Ministério do Meio Ambiente. Agenda 21 Local. Disponível em: <http://www.mma.gov.br/responsabilidade-socioambiental/agenda-21/agenda-21-local_. Acesso em: 23 set. 2017.

BRASIL. Ministério do Meio Ambiente. Agenda 21: articulando planos nos municípios. Caderno e debate. Agenda 21 e sustentabilidade. Secretaria de Políticas para o Desenvolvimento Sustentável. II Conferência Nacional de Meio Ambiente (CNMA), 2005.

BRASIL. Resolução do Conama, de 05 de julho de 2002. Estabelece os requisitos mínimos e o termo de referência para realização de auditorias ambientais. Diário Oficial da República Federativa do Brasil. Brasília, 19 de julho de 2002. Disponível em: <http://www.mma.gov.br/port/conama/res/res02/res30302.html_. Acesso em: 2 jun. 2017.

BRUNDTLAND, G. Our common future. New York: WCED, 1987.

BRÜSEKE, F. A crítica da técnica moderna. Estudos Sociedade e Agricultura, Rio de Janeiro, UFRRJ, nº 10, abril 1998.

CARDOSO, R. dos S.; AMORIM, M. C. de C. T. Características do clima urbano em Presidente Prudente/SP a partir de dados de temperatura e umidade relativa do ar e técnicas de sensoriamento remoto. Revista do Departamento de Geografia, USP, v. 28 p. 39-64, 2014.

CARVAlHO, N. L. de; KERSTING, C.; ROSA, G.; FRUET, L.; BARCELlOS, A. L. de. Desenvolvimento sustentável X Desenvolvimento econômico. Revista Monografias Ambientais 
Santa Maria. Revista do Centro de Ciências Naturais e Exatas - UFSM, v. 14, n. 3, p. 109-117, set-dez. 2015. DOI: 105902/2236130817768.

CARVAlHO JÚNIOR, O. A.; GUIMARÃES, R. F; CARVALHO A. P. F.; GOMES, R. A. T.; MELO, A. F.; SILVA, P. A. Processamento e análise de imagens multitemporais para o perímetro de irrigação de Gorutuba/MG. In: Actas XII Simpósio Brasileiro de Sensoriamento Remoto [internet]; 2005 abril 16-21; Goiânia, Brasil. 2005. Disponível em: <http://marte.sid.inpe.br/col/ltid.inpe.br/sbsr/2004/12.06.13.32/doc/473.pdf >. Acesso em: 13 jan. 2017.

CASTILHO, C. J. M.; SOEIRO; Í. C. M.; PONTES, B. A. N. M. Entre a supressão e a conservação da natureza na cidade: o fortalecimento da racionalidade ambiental para o resgate da beleza da paisagem. Revista Brasileira de Geografia Física, v. 09, n. 03, p. 852-867, 2016.

CONFERÊNCIA DAS NAÇÕES UNIDAS SOBRE MEIO AMBIENTE E DESENVOLVIMENTO - CNUMAD. Agenda 21. São Paulo: Secretaria de Estado do Meio Ambiente, 1997.

COMISSÃO MUNDIAL SOBRE MEIO AMBIENTE E DESENVOLVIMENTO. Nosso futuro comum. Rio de Janeiro: FGV, 1988.

CORRÊA, R. L. O espaço urbano. São Paulo: Ática, 2004. (Série Princípios).

EASTMAN, J. R. Idrisi Andes - Guide to GIS and Image Processing. Clark Laboratory. Worcester: Clark University, 2006.

EMDEJA. Relatório ambiental preliminar dos estudos de impactos ambientais do projeto de macrodrenagem do complexo hídrico Lagoa Olho d'Água - Estuário do Rio Jaboatão. Jaboatão dos Guararapes, 2003.

EPIPHANIO, J. C. N.; GLERIANI, J. M.; FORMAGGIO, A. R.; RUDORFF, B. F. T. Índices de vegetação no sensoriamento remoto da cultura do feijão. Pesquisa agropecuária brasileira, Brasília, v. 31, n. 6, p. 445-454, 1996.

ESTEVES, F. A. Lagoas costeiras: origem, funcionamento e possibilidade de manejo. In: ESTEVES, F. A. (Ed.). Ecologia das lagoas costeiras do Parque Nacional da Restinga de Jurubatiba e do município de Macaé (RJ), p. 64, 1998.

FEIO, A. C.; AGUIAR-DIAS, A. C. A. de. Relação sociedade-natureza: aspectos culturais na conservação ambiental. Diversidade e gestão. Gestão ambiental: perspectivas, conceitos e casos. Volume Especial v. 1, n. 1. p. 103-106, 2017.

FLORENZANO, T. G. Geotecnologias na geografia aplicada: difusão e acesso. Revista do Departamento de Geografia, v. 17, p. 24-29, 2005.

FRANÇA, A. F.; TAVARES JUNIOR, J. R.; MOREIRA FILHO, J. C. C. Índices NDVI, NDWI e NDBI como ferramentas ao mapeamento temático do entorno da Lagoa Olho d'Água, em Jaboatão dos Guararapes - PE. IV Simpósio Brasileiro de Ciências Geodésicas e Tecnologias da Geoinformação. UFPE, Recife - PE, p. 001-009, 06-09 de maio de 2012. 
FREITAS, D. A. de. A sustentabilidade como instrumento de alavancagem negocial em bancos privados no Brasil - Caso Santander. TCC Ciências Contábeis, UniCEUB - Centro Universitário de Brasília. 2013.

FREITAS, R. Entre mitos e limites: as possibilidades do adensamento construtivo face à qualidade de vida no ambiente urbano. Recife: Ed. Universitária da UFPE, 2008.

GEHLEN, V. Para além dos limites do urbano: áreas periurbanas e questão ambiental. Cadernos CERU, série 2, v. 21, n. 1, jun. 2010.

GILABERT, M. A.; GONZÁLEZ-PIQUERAS, J.; GARCÍA-HARO, F. J.; MELIA, J. A. Generalized soil-adjusted vegetation index. Remote Sensing of Environment, v. 82. p. 303-310, 2002.

GOMES, S. C.; LIMA, E. S. de; ALHEIROS, M. M. Diagnóstico ambiental do meio físico para gestão da bacia hidrográfica do Rio Jaboatão. II Congresso sobre Planejamento e Gestão das Zonas Costeiras dos Países de Expressão Portuguesa. IX Congresso da Associação Brasileira de Estudos do Quaternário. II Congresso do Quaternário dos Países de Língua Ibéricas. 2003.

GOMES, M. A. S. Parques urbanos, políticas públicas e sustentabilidade. Mercator, Fortaleza, v. 13, n. 2, p. 79-90, maio/ago. 2014. DOI: 10.4215/RM2014.1302.0006.

HANAZAKI, N.; HERBST, D.; MARQUES, M.; VANDEBROEK, I. Evidence of the shifting baseline syndrome in ethnobotanical research. Journal of Ethnobiology and Ethnomedicine, v. 9, n. $75,2013$.

HUETE, A. R. Adjusting vegetation indices for soil influences. International Agrophysics, v. 4, n. 4, p.367-376, 1988.

JABOATÃO DOS GUARARAPES. Plano Diretor de Jaboatão dos Guararapes. Lei complementar $\mathrm{n}^{\circ}$ 002, de 11 de janeiro de 2008. Jaboatão dos Guararapes, PE. 2008.

JENSEN, J. R. Sensoriamento remoto do ambiente: uma perspectiva em recursos terrestres. Tradução de: EPIPHANIO, José Carlos Neves et al. São José dos Campos, 2009.

KJERFVE, B. Coastal lagoon processes. Amsterdan: Elsevier Oceanography Series, 1984.

LEAL, J. P. Estudo geoambiental e evolução paleográfica da Lagoa Olho d'Água (Jaboatão dos Guararapes). Recife: UFPE, 2002.

LIMA, W. de P. Hidrologia florestal aplicada ao manejo de bacias hidrográficas. Piracicaba: Universidade de São Carlos, 1996.

LOUREIRO, D. D. Evolução do aporte de metais pesados na lagoa Rodrigo de Freitas. RJ. 120f. Dissertação - Instituto de Geociências, Universidade Federal Fluminense, Niterói, 2006.

MARKHAM, B. L.; BARKER, L. L. Thematic mapper bandpass solar exoatmospherical irradiances. International Journal of Remote Sensing, v. 8, n. 3, p. 517-523, 1987. 
MARTINS, K. G. Expansão urbana desordenada e aumento dos riscos ambientais à saúde humana: o caso brasileiro. Planaltina, p. 10-17, 2012.

MELESSE, A. M.; WENG, Q.; THENKABAIL, P. S.; SENAY, G. B. 2007. Remote sensing sensors and applications in environmental resources mapping and modelling. Sensors, 7, 3209-3241.

MELLO, S. S. de. Rios e lagos urbanos: urbanidade e valorização.XIII Encontro da associação nacional de pós-graduação e pesquisa em planejamento urbano e regional. 25 a 29 de maio de 2009. Florianópolis - Santa Catarina - Brasil.

MELO, J. G. da S.; SILVA, E. R. A. C.; GALVINCIO, J. D. Preservação ambiental e novas tecnologias de monitoramento ambiental: potencial do sensoriamento remoto para avaliação da degradação ambiental em zonas estuarinas. Revista educação ambiental em ação, ano XVI, n. 61, 2017.

MENDES, M. C. Desenvolvimento sustentável. Disponível em: <http://educar.sc.usp.br/biologia/textos/m_a_txt2.html>. Acesso em: 20 set. 2016.

MENESES, P. R. Fundamentos de radiometria óptica espectral. In: MENESES, P. R.; NETTO, J. S. M. Sensoriamento remoto: reflectância dos alvos naturais. Brasília: UnB; Planaltina: Embrapa Cerrados, 2001.

MUCELIN, C. A.; BELLINI, M. Lixo e impactos ambientais perceptíveis no ecossistema urbano. Sociedade \& Natureza. Minas Gerais: Uberlândia, ano 20, n. 1, jun. 2008.

MULLER, C. C.; MARTINE, G. Modernização da agropecuária, emprego agrícola e êxodo rural no Brasil - A década de 1990. Revista de Economia e Política, v. 17, n. 3, p. 67, jul./set. 1997.

NASCIMENTO, A. P. do. Análise dos impactos das atividades antrópicas em lagoas costeiras Estudo de caso da Lagoa Grande em Paracuru - CE. Dissertação. Universidade Federal do Ceará. Fortaleza- CE, 2010.

NOVAES, J. A. M. Análise do processo de evolução da expansão urbana no entorno da Rodovia PE-15. Dissertação, UFPE. Recife, 2010.

NOVO, E. M. L. M. Sensoriamento remoto: princípios e aplicações. São Paulo: Blucher, 2008.

OLIVEIRA, T. H.; SILVA, J. S.; MACHADO C. C. C.; GALVÍNCIO, J. D.; PIMENTEL, R. M. M. Índice de Umidade (NDWI) e Análise Espaço-Temporal do Albedo da Superfície da Bacia Hidrográfica do Rio Moxotó - PE. Revista Brasileira de Geografia Física, v. 03, p. 55-69, 2010.

OLIVEIRA, A. U. Agricultura e indústria no Brasil. Campo-território: Revista de Geografia Agrária, v. 5, n. 10, p. 5-64, ago. 2010.

PAIVA, S. C. de; SAlGUEIRO, A. A. Impacto ambiental na Lagoa Olho d'Água em Jaboatão dos Guararapes - PE. Revista Química \& Tecnologia, ano 1, n. 1, p. 39-43, jul./dez. 2002.

PASSMORE, J. Atitudes frente à natureza. Revista de Geografia, UFPE, v. 11, p. 91-102, 1995. 
PEREIRA, M. N.; KURKDJIAN, M. L. N. O.; FORESTI, C. Cobertura e uso da terra através de sensoriamento remoto. São José dos Campos: Instituto de Pesquisas Espaciais, 1989.

PINHEIRO, C.; LARANJEIRA, M. Análise do ambiente térmico e das condições de ventilação para a definição das funções climáticas na área urbana de Guimarães. Revista de Geografia e Ordenamento do Território (GOT). Centro de Estudos de Geografia e Ordenamento do Território, n. 4, p. 249-272, dez.2013.

PONZONI, F. J. Comportamento espectral da vegetação. In: MENESES, P. R., NETTO, J. S. M. (Orgs.). Sensoriamento remoto, reflectância dos alvos naturais. Brasília: Editora Universidade de Brasília; Embrapa Cerrados, 2001. p. 157-199.

PONZONI, F. J.; SHIMABUKURO, Y. E. Sensoriamento remoto no estudo da vegetação. São José dos Campos: Parêntese, 2010.

RODRIGUES, José Eduardo Ramos; SALLES, Cíntia Philippi; PHILIPPI JUNIOR, Arlindo. Agenda 21 - Estágio do compromisso brasileiro para o desenvolvimento sustentável do país. Revista de Direito Ambiental; Revista dos Tribunais, São Paulo, ano 6, n. 23, p. 285, jul./set. 2001.

SANTOS, M. L. F.; KATO, M. Influência do saneamento ambiental na preservação da Lagoa Olho d'Água. In: Associação Brasileira de Engenharia Sanitária e Ambiental. Trabalhos técnicos. Rio de Janeiro: ABES, 1997. p.13.

SILVA, E. R. A. C.; MELO, J. G.; GALVINCIO, J. D. Identificação das áreas susceptíveis a processos de desertificação no médio trecho da Bacia do Ipojuca - PE através do mapeamento do estresse hídrico da vegetação e da estimativa do índice de aridez. Revista Brasileira de Geografia Física, v. 4, n. 3, p. 629-649, 2011.

SILVA, E. R. A. C., GALVÍNCIO, J. D., BRANDÃO NETO, J. L., MORAIS, Y. C. B. Space-time analysis of environmental changes and your reflection on the development of phonological of vegetation of mangrove. Journal of Agriculture and Environmental Sciences, v. 4, p. 245-253, 2015.

SOARES, F. B.; LEAL, A. C. Planejamento ambiental da bacia do Balneário da Amizade nos municípios de Álvares Machado e Presidente Prudente - São Paulo. In: Fórum Ambiental da Alta Paulista, 2, 2011, Tupã. Anais... Tupã: ANAP, 2011. p. 75-93.

SOBRINHO, C. A. Desenvolvimento sustentável: uma análise a partir do Relatório Brundtland. Dissertação, Faculdade de Filosofia e Ciências da Universidade Estadual Paulista Júlio de Mesquita Filho, Marília, SP. 2008.

SOUTO F. J. B.Sociobiodiversidade na pesca artesanal no litoral da Bahia. In: KUBO, R. R.; BASSI, J. B.; Souza, G. C.; ALENCAR, N. L.; MEDEIROS, P. M.; ALBUQUERQUE, U. P. (Orgs.). Atualidades em etnobiologia e etnoecologia. Recife: Nupeea/Sociedade Brasileira de Etnobiologia e Etnoecologia, 2006. p. 259-274.

TENÓRIO, B. C. A Lagoa Olho d'Água: o sistema de uma paisagem. Dissertação (Mestrado) Universidade Federal de Pernambuco. Centro de Artes e Comunicação. Desenvolvimento Urbano, Recife, 2013. 
TASUMI, M. Progress in operational estimation of regional evapotranspiration using satellite imagery. Idaho: University of Idaho, 2003.

TUNDISI, J. G.; MATSUMURA-TUNDISI, T. Limnologia. São Paulo: Oficinas de Textos, 2008.

VIGANÓ, H. A.; BORGES, E. F.; FRANCA-ROCHA, W. J. S. Análise do desempenho dos índices de vegetação NDVI e Savi a partir de imagem Aster. [versão eletrônica] Anais... XV Simpósio Brasileiro de Sensoriamento Remoto - SBSR, Curitiba, PR, Brasil, Inpe, p.1828. 2011.

VILLAÇA, F. Espaço intra-urbano no Brasil. São Paulo: Fapesp, 2001.

WENG, Q.; QUATTROCHI, D. A. Urban remote sensing. CRC Press/Taylor and Francis, p. 448. 2006.

ZHA, Y.; GAO, J.; NI, S. Use of normalized difference built-up index in automatically mapping urban areas from TM imagery. International Journal of Remote Sensing, v. 24, n. 3, p. 583-594, 2003.

Artigo recebido em 04/08/2017. Aceito para publicação em 03/10/2017. 